\title{
Methods for priming maize seeds ${ }^{1}$
}

\author{
Dryelle Sifuentes Pallaoro ${ }^{2 *}$, Elisangela Clarete Camili², \\ Sebastião Carneiro Guimarães ${ }^{2}$, Maria Cristina de Figueiredo e Albuquerque ${ }^{2}$
}

\begin{abstract}
This study aimed to evaluated different methodologies and water potentials for priming of maize seeds, in order to increase vigor. The experiment was carried out following a completely randomized design, in a factorial scheme $4 \times 3+1$, with four water potentials $(0.0,-0.4,-0.8$ and $-1.2 \mathrm{MPa})$, three priming methods (immersion in non-aerated solution, immersion in aerated solution, paper roll) and a control. After priming, the seeds were dried and evaluated for water content, percentage and first germination count, seedlings length and dry mass, cold test and vigor index. The water potential recommended for priming maize seeds, in polyethylene glycol 6000 is $-0.4 \mathrm{MPa}$ for 24 hours. The priming procedures in towel paper rolls improve the quality of maize seeds.
\end{abstract}

Index terms: osmo-priming, polyethylene glycol, vigor, Zea mays L.

\section{Métodos para o condicionamento fisiológico de sementes de milho}

\begin{abstract}
RESUMO - Objetivou-se avaliar diferentes metodologias e potenciais hídricos para o condicionamento fisiológico de sementes de milho, visando o aumento no vigor. O experimento foi realizado em delineamento inteiramente casualizado, esquema fatorial diferenciado $4 \times 3+1$, com quatro potenciais hídricos $(0,0,-0,4,-0,8$ e -1,2 MPa), três métodos de condicionamento (imersão em solução não aerada, imersão em solução aerada e rolo de papel) mais a testemunha. Após o condicionamento fisiológico as sementes foram secas e avaliadas quanto ao teor de água, porcentagem e primeira contagem da germinação, comprimento e massa seca das plântulas, teste de frio e índice de vigor. O potencial hídrico recomendado para o condicionamento fisiológico de sementes de milho, em polietilenoglicol 6000 é de -0,4 MPa por 24 horas. O condicionamento em rolo de papel 'germitest' eleva a qualidade de sementes de milho.
\end{abstract}

Termos para indexação: osmocondicionamento, polietilenoglicol, vigor, Zea mays L.

\section{Introduction}

In maize crops, when seeds are not used for sowing in the year of production and validity, they can be reevaluated on their physiological quality, repackaged and stored until the next harvest, since the high cost of marketing and chemical treatment received at the processing prevent them from being resold for food purposes. Thus, due to a longer storage life, these seeds will be more susceptible to a decrease in vigor and viability.

In this sense, the use of priming may be an alternative, avoiding the disposal of the seeds as well as environmental contamination. Priming or physiological conditioning is based on the controlled hydration of the seeds, so that pregermination metabolic process begins without radicle protrusion (Heydecker et al., 1975). Among the improvements achieved through priming, can be mentioned the increase in germination percentage, germination speed, length and seedling dry mass, as well as the increase in the ability of seeds to withstand stress during germination (Arif et al., 2010; Arif et al., 2014; Dezfuli et al., 2008; Khalil et al., 2001; Masetto et al., 2013; Oliveira and Gomes Filho, 2010; Pereira et al., 2008; Sediyama et al., 2012; Yasari, et al., 2013).

The various seed hydration techniques may influence the response to physiological conditioning (Balbinot and Lopes, 2006), therefore, this procedure can be performed in many different ways, such as seed soaking in humid atmosphere, and hydric and matrix-priming; however, osmo-priming stands out, as it allows the regulation of water flow through an osmotic agent. In general, to control water uptake by seeds, be may use polyethylene glycol (PEG), an osmotically active solute, which is also chemically inactive, nontoxic, and has a high molecular weight (Marcos -Filho, 2015).

\footnotetext{
${ }^{1}$ Submitted on 03/14/2016. Accepted for publication on 05/09/2016.

${ }^{2}$ Departamento de Fitotecnia e Fitossanidade, UFMT, 78060-900- Cuiabá, Brasil.

*Corresponding author: <dryelle_pallaoro@hotmail.com>
} 
During the treatment with PEG, the seed hydrates slowly, enabling membrane repair and reorganization due to a longer period of time (Menezes et al., 2006) and a lower soaking speed. However, these solutions have high viscosity, which can compromise oxygen absorption by seeds (Yoon et al., 1997), and thus aeration of the conditioning solution may be necessary.

In addition of soaking method factor, there are other factors that affect the success of the procedure such as water potential, time and temperature of priming. Among the water potentials applied, several recommendations can be found, ranging from $-0,05$ to $-1,8 \mathrm{MPa}$, either for maize crop or other species (Ghiyasi et al., 2011; Arif et al., 2014; Bakht et al., 2011; Ghiyasi et al., 2008; Oliveira et al., 2007; Sediyama et al., 2012). Thus, it was aimed to evaluate different methodologies and water potentials for priming of maize seeds, seeking to improve vigor.

\section{Material and Methods}

In order to reproduce the concrete reality confronted by farmers, this study used hybrid maize seeds DKB 390 VT PRO2, produced in the 2013/2013 harvest, chemically treated with deltamethrin, pirimiphos-methyl, metalaxyl, thiabendazole, fludioxonil and alkyl phenol polyoxyethylene, provided by Monsanto Company. As the seeds available for the experiment displayed a high vigor level, they remained stored in a covered nursery, under non controlled temperature (min. $22.5^{\circ} \mathrm{C}$, avg. $27.5^{\circ} \mathrm{C}$ and $\max .32 .0^{\circ} \mathrm{C}$ ) and relative humidity of the air (min. 49.0\%; avg. 59.4\% and max. $75.0 \%$ ), for four months, until a significant reduction in the seed quality was noticed.

Upon receiving the seeds, these presented $11.1 \%$ of water content, $97 \%$ of germination and $93 \%$ of germination in the first count. After storage, the seeds displayed $9.4 \%$ of water content; $83 \%$ of germination and $78 \%$ of germination in the first count. Thus, the experiment was carried out in a completely randomized design, in a factorial scheme $3 \mathrm{x} 4+1$ (three priming methods $\mathrm{x}$ four water potentials + control), with four replications.

The treatments consisted of seeds primed by immersion in a non-aerated solution (NAS), in an aerated solution (AS) and towel paper rolls (PR), in different water potentials: 0.0 , $-0.4,-0.8$ and $-1.2 \mathrm{MPa}$. During conditioning, the temperature was kept at $24 \pm 1{ }^{\circ} \mathrm{C}$ with a photoperiod of 12 hours. The priming time was determined by the soaking curve in the four potentials assessed, and a period of 24 hours was chosen once, during this period, radicle protrusion would not occur.

To evaluate seed imbibition methodologies, $195 \mathrm{~g}$ of seeds were immersed in $500 \mathrm{~mL}$ of polyethylene glycol solution per plot, with and without aeration. Aeration took place through the connection of two plastic beakers to two air inlets in the lower portion of the container, which were coupled to aeration pumps to inject air into the solution.

In the priming procedure using paper rolls, each paper roll consisted of four sheets of towel paper moistened with PEG solutions in a ratio of three times of dry paper mass. As in the methodologies previously described, the amount of seed was standardized to $195 \mathrm{~g}$, which was divided into five rolls in order to allow all the seeds to have contact with the paper during the conditioning process. Rolls were placed in plastic boxes to maintain moistened. At the end of the conditioning procedure, in all methodologies evaluated, the seeds were dried in an oven with forced air circulation at $40{ }^{\circ} \mathrm{C}$, for nine hours, a period of time defined in pre-tests.

The seed water content was determined by the oven-drying method (Brasil, 2009). The seed quality was evaluated by the following tests: germination percentage and germination at first count in towell paper roll at $30{ }^{\circ} \mathrm{C}$, counting the number of normal seedlings in the 7th and 4th day after sowing, respectively (Brasil, 2009); cold test in towel paper rolls (Barros et al., 1999); seedlings length and dry mass on the 5th day after sowing, following methodology described by Nakagawa, 1999; and vigor index (product between the germination percentage and the average seedling length) (Abdul-Baki and Anderson, 1973). The dissolved oxygen content in solutions was also assessed with an oximeter YSI 55 , before and after priming.

These data were submitted to analysis of variance; when significant values were found, the Scott-Knott test was applied $(\mathrm{p}<0.05)$ and the control average was compared with the treatments means by Dunnett test $(\mathrm{p}<0.05)$. Subsequently, Pearson's correlation analysis between vigor variables and water content was performed. The correlation coefficients were classified as very strong $(|\mathrm{r}|>0.8)$, strong $(0.6<|\mathrm{r}|<$ $0.8)$, moderate $(0.4<|\mathrm{r}|<0.6)$, weak $(0.2<|\mathrm{r}|<0.4)$ and negligible $(|\mathrm{r}|<0.2)$ (Franzblau, 1958).

\section{Results and Discussion}

The initial water content of maize seeds was $9.4 \%$ and, after a 24-hour priming, the seeds displayed different percentages of water content in the different treatments (Table 1). An increased water restriction in the solution generated a reduction in the final water content due to the limited absorption imposed by the polyethylene glycol. After drying, the water content did not return to baseline values (Table 1), since the 9-hour drying cycle was not enough to remove all the water absorbed during priming. 
Table 1. Water content (\%) of maize seeds (Zea mays L.) submitted to priming in solutions of PEG 6000 in different water potentials $(\Psi \mathrm{w})$ through immersion in non-aerated solution (NAS), immersion in aerated solution (AS) and paper roll (PR), after conditioning (AC) and drying (AD).

\begin{tabular}{ccccc}
\hline & \multirow{2}{*}{$\Psi_{\mathrm{w}}$} & & \multicolumn{3}{c}{ Priming method } \\
\cline { 3 - 5 }$(\mathrm{MPa})$ & & $\mathrm{NAS}$ & $\mathrm{AS}$ & $\mathrm{PR}$ \\
\hline \multirow{2}{*}{0.0} & $\mathrm{AC}$ & 34.1 & 33.9 & 31.9 \\
& $\mathrm{AD}$ & 16.2 & 18.4 & 16.3 \\
\hline \multirow{2}{*}{-0.4} & $\mathrm{AC}$ & 29.9 & 30.6 & 27.8 \\
& $\mathrm{AD}$ & 14.8 & 14.8 & 14.1 \\
\hline \multirow{2}{*}{-0.8} & $\mathrm{AC}$ & 27.0 & 28.2 & 26.1 \\
& $\mathrm{AD}$ & 14.5 & 14.9 & 16.9 \\
\hline \multirow{2}{*}{-1.2} & $\mathrm{AC}$ & 25.6 & 25.3 & 23.5 \\
& $\mathrm{AD}$ & 13.9 & 13.7 & 12.6 \\
\hline \multicolumn{2}{c}{ Initial water contente } & & 9.4 \\
\hline
\end{tabular}

In contrast to the water content of the seeds before priming (9.4\%), in the treatment with higher water content after drying, i.e., the hydro-primed seed by immersion in aerated solution (18.4\%), a wide range of 8.97 percentage points was observed. Using the soaking curve of seeds with no water restriction, $0.0 \mathrm{MPa}$ (Figure 1), it is clear that this difference in water content represents 4.4 hours. In other words, this seed with $9.43 \%$ of moisture, when soaked in water, will take four hours and 24 minutes to reach the same water content reached by the seed that was hydro-primed in an aerated solution for 24 hours and dried for nine hours at $40{ }^{\circ} \mathrm{C}$.

Therefore, due to this difference in the seeds water content in different treatments, a correlation analysis of data concerning water content after drying and vigor variables was carried out (Table 2). It was observed that the correlation coefficient was moderately significant and positive between the seed water content after drying and the first germination count, indicating a relationship between these variables (Table 2).

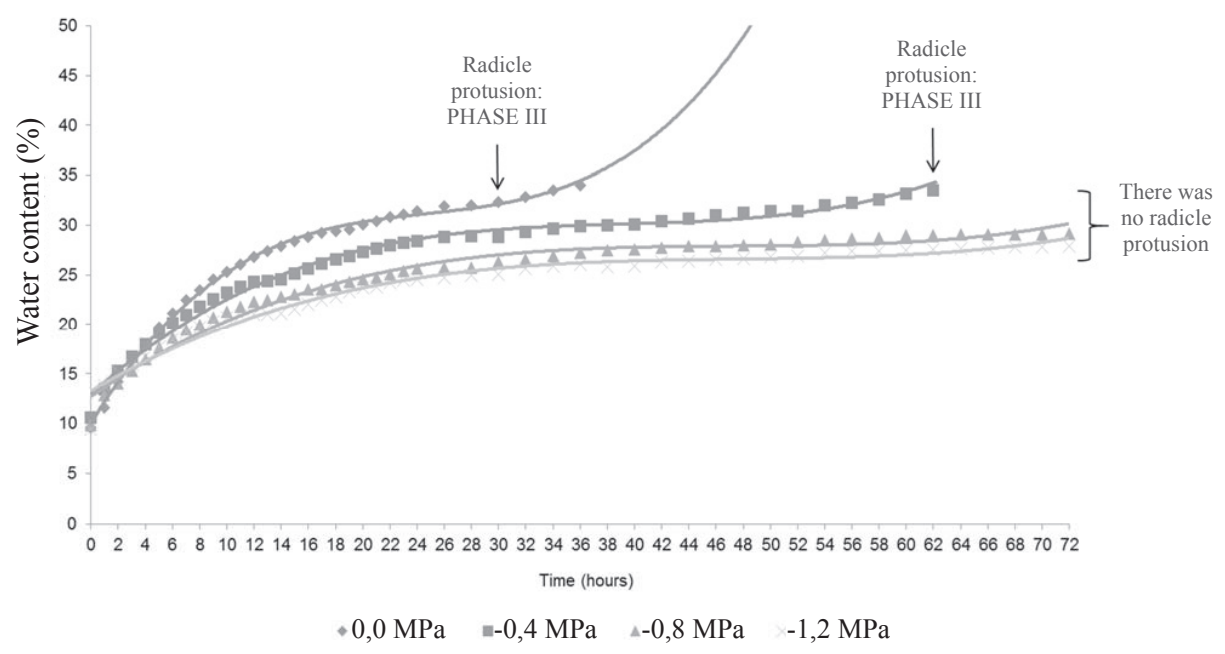

Figure 1. Soaking curves of maize seeds (Zea mays L.) in solutions of polyethylene glycol (PEG 6000) at 0.0, -0.4, -0.8 and $-1.2 \mathrm{MPa}$ potentials.

Table 2. Pearson's simple correlation coefficients between water content after drying (WC), first germination count (FGC), germination after the cold test (CT), seedlings length (SL), seedling dry mass (SDM) and vigor index (VI) of maize seeds (Zea mays L.).

\begin{tabular}{ccccccr}
\hline & WC & FGC & CT & SL & SDM & VI \\
\hline WC & 1 & $0.589^{*}$ & $0.178^{\mathrm{NS}}$ & $0.162^{\mathrm{NS}}$ & $0.177^{\mathrm{NS}}$ & 0.36 \\
FGC & & 1 & $0.449^{*}$ & $0.284^{*}$ & $0.356^{*}$ & 0.68 \\
CT & & & 1 & $0.193^{\mathrm{NS}}$ & $0.304^{*}$ & 0.31 \\
SL & & & & 1 & $0.835^{*}$ & 0.86 \\
SDM & & & & & 1 & 0.77 \\
VI & & & & & & 1 \\
\hline
\end{tabular}

* Statiscally significant as revealed by $\mathrm{t}$ test $(\mathrm{P}<0.05)$.

Ns Non significant.
The water content of the seeds after priming may have influenced the results of the first germination count, as this test is based on the determination of germinated seeds within four days of sowing, which can lead to a greater sensitivity to variations, due to a shorter time until the reading task is accomplished. On the other hand, for the other variables, the difference in water content was less representative, with weak or no significant correlation.

Regarding the percentage and first germination count, seedlings length and dry mass, cold test and vigor index, the water potential factor was significant, but there was no interaction among the factors "priming method" and "water potential". In the germination percentage, potentials of -0.4 and $-0.8 \mathrm{MPa}$ were higher with 97 and $95 \%$ of germination, 
respectively (Table 3).

The same pattern was observed in germination after the cold test, in which higher germination values were observed in seeds primed in -0.4 and $-0.8 \mathrm{MPa}$, after undergoing thermic stress, demonstrating that in an adverse environmental condition the seeds submitted to these treatments can sprout. These results also allow a comparison between treatments, in relation to their performance in a favorable situation, provided by standard germination test, and in an unfavorable situation, provided by the cold test; therefore, potentials of -0.4 and $-0.8 \mathrm{MPa}$ have been highlighted in both conditions (Table 3 ).

Table 3. Germination percentage (GP) and first germination count (FGC), germination after the cold test (CT), seedling length (SL), seedling dry mass (SDM) and vigor index of maize seeds (Zea mays L.) submitted to priming in a solution of PEG 6000 in different water potentials $(\Psi \mathrm{w})$.

\begin{tabular}{|c|c|c|c|c|c|c|}
\hline$\Psi_{\mathrm{w}}(\mathrm{MPa})$ & GP & FGC (\%) & CT & SL ( $\left(\mathrm{cm}\right.$.seedling $\left.{ }^{-1}\right)$ & SDM (mg .seedling $\left.{ }^{-1}\right)$ & VI \\
\hline 0.0 & $93 \mathrm{~b}$ & $93 \mathrm{a}$ & $86 \mathrm{~b}$ & $40.2 \mathrm{a}$ & $64.6 \mathrm{a}$ & $3,752.7 \mathrm{~b}$ \\
\hline-0.4 & $97 \mathrm{a}$ & $96 \mathrm{a}$ & $92 \mathrm{a}$ & $40.9 \mathrm{a}$ & $67.6 \mathrm{a}$ & $3,955.9 \mathrm{a}$ \\
\hline-0.8 & $95 \mathrm{a}$ & $93 \mathrm{a}$ & $91 \mathrm{a}$ & $37.2 \mathrm{~b}$ & $61.4 \mathrm{~b}$ & $3,534.9 \mathrm{c}$ \\
\hline-1.2 & $93 \mathrm{~b}$ & $89 \mathrm{~b}$ & $81 \mathrm{c}$ & $36.7 \mathrm{~b}$ & $58.0 \mathrm{~b}$ & $3,398.3 \mathrm{c}$ \\
\hline Control & 83 & 78 & 85 & 38.15 & 60.2 & $3,160.3$ \\
\hline CV (\%) & 3.2 & 4.1 & 5.9 & 5.6 & 7.7 & 6.2 \\
\hline
\end{tabular}

Means followed by the same letter, in the column, do not differ significantly by the Scott-Knott test $(\mathrm{P}<0.05)$.

For the average of the first germination count, water potentials of $0.0,-0.4,-0.8 \mathrm{MPa}$ were higher than -1.2 MPa (Table 3). Comparing the results of percentage and first germination count in different treatments with the control, gains were observed after priming (Table 4). Hence, conditioning in water $(0.0 \mathrm{MPa})$ and in PEG solution of -0.4 and -0.8 MPa improved the physiological attributes of maize seeds. In absolute values, the water potential of $-0.4 \mathrm{MPa}$ stood out from the others (Table 3 and Table 4), demonstrating that priming in PEG 6000 increased the vigor level, so that a greater number of seeds were germinated, with developed roots and shoot on fourth and seventh days after sowing.

Table 4. Average of germination percentage (GP) and first germination count (FGC) of maize seeds (Zea mays L.) submitted to priming in a solution of polyethylene glycol 6000 , in different water potentials $(\Psi \mathrm{w})$, through immersion in nonaerated solution (NAS), immersion in aerated solution (AS) and paper roll (PR).

\begin{tabular}{ccccccc}
\hline \multirow{2}{*}{$\Psi_{\mathrm{w}}(\mathrm{MPa})$} & \multicolumn{3}{c}{ GP $(\%)$} & & FGC (\%) & \\
\cline { 2 - 6 } & NAS & AS & PR & NAS & AS & PR \\
\hline 0.0 & $92^{*}$ & $93^{*}$ & $95^{*}$ & $92^{*}$ & $92^{*}$ & $94^{*}$ \\
-0.4 & $98^{*}$ & $95^{*}$ & $98^{*}$ & $97^{*}$ & $95^{*}$ & $96^{*}$ \\
-0.8 & $97^{*}$ & $94^{*}$ & $95^{*}$ & $94^{*}$ & $92^{*}$ & $94^{*}$ \\
-1.2 & $93^{*}$ & $92^{*}$ & $93^{*}$ & 90 & 88 & 89 \\
\hline Control & & 83 & & 78 & 4.1 \\
\hline CV $(\%)$ & & 3.2 & & & \\
\hline
\end{tabular}

*Means differ from the control by Dunnett test $(\mathrm{P}<0.05)$.

According to Marcos-Filho (2015), in general, the quiescent seed, when the soaking process begins, has a disorganized plasma membrane due to the desiccation that takes place after maturation. Thus, when the dried seeds start the absorption process, a fast water intake occurs, which can result in leakage of cellular solutes derived from disorganized membranes. Such damage may be severely attenuated with a slow water absorption.

In this way, when water flow to the inner part of the seed was regulated by polyethylene glycol solution, the soaking rate decreased, reducing cell leakage and the occurrence of damages caused by soaking. Possibly, this process provides a higher germination percentage due to the decrease in the number of abnormal seedlings. This effect was also observed in soybean seeds by Sediyama et al. (2012), who found that slow water absorption by the seed, because of osmopriming, prevented injury and damage caused by imbibition process. Studding maize drying, Rosa et al. (2000) found that imbibition of dry seeds can cause damage, and the intensity of damage was associated with the existent initial damage. A 
disordered water absorption can allow the occurrence of cell injury (Marcos - Filho, 2015).

In seedling length and dry weight tests, a difference between water potentials was observed, in which 0.0 and -0.4 MPa stood out (Table 3), producing higher and heavier seedlings, therefore stronger. These characteristics also showed a strong positive correlation (Table 2). This finding demonstrates that the increase in length is associated with an increase in mass, ensuring optimal growth of seedlings. When elongation occurs without or with the addition of low rates of dry matter, a thin and weak seedling sprout, being susceptible to downfall. According to Nakagawa (1999), more vigorous seeds can develop normal seedlings with greater length and higher mass, as they are able to transfer higher dry mass from storage tissues to the embryonic axis during germination.

Regarding the vigor rate, water potentials differed from each other in which -0.4 MPa was higher (Table 3). This index is given by the product between germination percentage and the average seedling length, combining vigor and viability; thus gains in both physiological characteristics, i.e. quality attributes, were observed in seeds primed in solution of polyethylene glycol 6000 of $-0.4 \mathrm{MPa}$.

Increases in vigor levels and gains in comparison with the control were observed in maize (Ramezani and Sokht-Abandani, 2013) and rice seeds (Sokht-Abandani and Ramezani, 2012) conditioned in polyethylene glycol. According to Dezfuli et al. (2008), hydro-priming of maize seeds provided an increase in vigor levels, while priming in -1.2 MPa for 96 hours was shown to be harmful. This degenerative effect may be due to the use of a solution with a high water potential for a long period of immersion.

Regarding the priming method, differences in seedlings length and mass and vigor index were observed, particularly in towel paper roll (Table 5). This possibly occurred due to fact that in paper roll, the absorption takes place slowly in comparison with immersion, since the water content of the seed after priming was lower (Table 1). This may be related to the fact that the seeds had a reduced contact surface with the towel paper when compared with treatments, in which the seeds were immersed in the priming solution.

Table 5. Average of seedling length (SL), seedling dry mass (SDM) and vigor index (VI) of maize seeds (Zea mays L.) submitted to priming in a solution of polyethylene glycol 6000, through immersion in non-aerated solution (NAS), immersion in aerated solution (AS) and paper roll (PR).

\begin{tabular}{cccc}
\hline Priming method & SL $\left(\mathrm{cm}\right.$.seedling $\left.{ }^{-1}\right)$ & SDM $\left(\mathrm{mg}\right.$.seedling $\left.{ }^{-1}\right)$ & VI \\
\hline NAS & $37.9 \mathrm{~b}$ & $60.6 \mathrm{~b}$ & $3,587.1 \mathrm{~b}$ \\
AS & $37.7 \mathrm{~b}$ & $61.5 \mathrm{~b}$ & $3,534.9 \mathrm{~b}$ \\
PR & $40.7 \mathrm{a}$ & $66.6 \mathrm{a}$ & $3,859.4 \mathrm{a}$ \\
Control & 38.15 & 60.2 & $3,160.3$ \\
\hline CV $(\%)$ & 5.6 & 7.7 & 6.2 \\
\hline
\end{tabular}

Means followed by the same letter, in the column, do not differ significantly by the Scott Knott test $(\mathrm{P}<0.05)$.

For percentage and first germination count and cold test, no differences were found between methodologies. In general, the lack of differences between immersion treatments with and without aeration may be associated with a low demand for $\mathrm{O}_{2}$ during phases I and II of the germination process. During priming, oxygen was required in small quantities, once the process has been interrupted in the phase II of the germination. Regardless of the aeration process, there was a sufficient level of dissolved oxygen to supply the needs of the seeds during both phases, because even the treatment with the densest solution, $-1.2 \mathrm{MPa}$, contained $4.42 \mathrm{mg}$. $\mathrm{L}^{-1}$ of dissolved oxygen after physiological conditioning of the seeds (Table 6). For priming in towel paper roll, there is no restriction on $\mathrm{O}_{2}$ availability.

According to Marcos-Filho (2015), during the phase I there is a faster respiration process attributed to enzyme activation and hydration, however, the respiratory quotient $\left(\mathrm{RQ}=\mathrm{CO}_{2} \mathrm{O}_{2}^{-1}\right)$ in this phase is somewhat less 1 , and sucrose is the main substrate.
In phase II, the oxygen intake is stabilized, and RQ is higher than 1 , indicating the occurrence of fermentation and therefore anaerobic respiration. Fermentation occurs in the early stages of germination, and only after a certain period of time the oxygen demand increases, at the beginning of phase III, with the radicle protrusion and intensification of aerobic respiration.

In general, problems regarding oxygen availability may be related to physiological conditioning with long soaking periods and no aeration. In the present research, priming in PEG 6000 of $-1.2 \mathrm{MPa}$ for 24 hours, led to an increase in germination percentage and first germination count, in comparison with the control (Table 3), thus, there were no degenerative effects.

For soybean seeds, Khalil et al. (2001) state that priming for a period exceeding 48 hours reduces germination and may have harmful effects. Pereira et al. (2008) state that, in carrot seeds, priming in aerated solution of PEG of $-1.2 \mathrm{MPa}$, for 
four days, led to improvements in vigor and viability. Dezfuli et al. (2008) reported that priming with PEG 6000 of -1.2 MPa for 96 hours was harmful, reducing the percentage of maize seed germination.

Table 6. Dissolved oxygen (mg. $\mathrm{L}^{-1}$ ) in solutions of polyethylene glycol 6000 in different water potentials $\left(\Psi_{\mathrm{w}}\right)$, after maize seeds priming (Zea mays $\mathrm{L}$.) through immersion in non-aerated solution (NAS), aerated solution (AS) and paper roll (PR).

\begin{tabular}{ccccc}
\hline$\Psi_{\mathrm{w}}(\mathrm{MPa})$ & 0.0 & -0.4 & -0.8 & -1.2 \\
\hline SS & 5.74 & 5.24 & 4.99 & 4.94 \\
NAS & 4.30 & 4.74 & 4.76 & 4.42 \\
AS & 6.82 & 5.66 & 5.32 & 4.83 \\
PR & - & - & - & - \\
\hline
\end{tabular}

SS: standard solution - before seed conditioning.

Therefore, among the evaluated priming methods, towel paper roll allowed seedling development, with greater vigor, length and mass. However, for maize priming on a large scale, seed immersion in non-aerated solution is recommended, as the other parameters assessed did not revealed any difference between immersion in non-aerated solution, aerated solution and paper roll.

\section{Conclusions}

Water potential recommended for maize seeds priming, in polyethylene glycol 6000 , is $-0.4 \mathrm{MPa}$, during a 24 -hour soaking period.

Priming using towel paper rolls improves the quality of maize seeds.

\section{References}

ABDUL-BAKI,A.A.;ANDERSON,J.D. Vigourdeterminationinsoybeanseed by multiple criteria. Crop Science, v.13, p.630-633, 1973. https://dl.sciencesocieties. org/publications/cs/abstracts/13/6/CS0130060630?access $=0 \&$ view=pdf

ARIF, M.; JAN, M. T.; MIAN, I. A.; KHAN, S. A.; HOLLINGTON, P.; HARRIS, D. Evaluating the impact of osmopriming varying with polyethylene glycol concentrations and durations on soybean. International Journal of Agriculture and Biology, v.16, n.2, p.359-364, 2014. http://www. fspublishers.org/published_papers/74610_..pdf

ARIF, M.; JAN, M. T.; KHAN, N. U.; KHAN, A.; KHAN, M. J.; MUNIR, I. Effect of seed priming on growth parameters of soybean. Pakistan Journal of Botany, v.42, n.4, p.2803-2812, 2010. http://www.pakbs.org/pjbot/ PDFs/42\%284\%29/PJB42\%284\%292803.pdf

BALBINOT, E.; LOPES, H.M. Efeitos do condicionamento fisiológico e da secagem na germinação e no vigor de sementes de cenoura. Revista Brasileira de Sementes, v.28, n.1, p.01-08, 2006. http://www.scielo.br/scielo. php?script=sci_arttext\&pid=S0101-31222006000100001
BAKHT, J.; SHAFI, M.; SHAH, R.; RAZIUDDIN; MUNIR, I. Response of maize cultivars to various priming sources. Pakistan Journal of Botany, v.43, n.1, p.205-212, 2011. https://www.researchgate.net/publication/268181155_ Response_of_maize_cultivars_to_various_priming_sources

BARROS, A. S. R.; DIAS, M. C. L. L.; CÍCERO, S. M.; KRZYZANOWSKI, F. C. Teste de frio. In: KRZYZANOWSKI, F. C.; VIEIRA, R. D.; FRANÇANETO, J. B. (Eds.). Vigor de sementes: conceitos e testes. Londrina: ABRATES, cap.5, 1999. 218p.

BRASIL. Ministério da Agricultura, Pecuária e Abastecimento. Regras para análise de sementes. Ministério da Agricultura, Pecuária e Abastecimento. Secretaria de Defesa Agropecuária. Brasília: MAPA/ACS, 2009. 395p. http:// www.agricultura.gov.br/arq_editor/file/2946_regras_analise_sementes.pdf

DEZFULI, P. M.; SHARIF-ZADEH, F.; JANMOHAMMADI, M. Influence of priming techniques on seed germination behavior of maize inbred lines (Zea mays L.). Journal of Agricultural and Biological Science, v.3, n.3, p.22-25, 2008. http://www.arpnjournals.com/jabs/research_papers/rp_2008/ jabs_0508_79.pdf

FRANZBLAU, A. A primer of statistic for non statisticians. New York: Harcourt, Brace \& World, 1958.150p.

GHIYASI, M.; TAJBAKHSH, R.; AMIRNIA, R. Effect of osmopriming on harvested seed vigor of maize (Zea Mays L.). Advances in Environmental Biology, v.5, n.11, p.3540-3542, 2011. http://www.aensiweb.com/old/ aeb/2011/3540-3542.pd

GHIYASI, A.; MYANDOAB, M.P.; TAJBAKHSH, M.; SALEHZADE, H.; MESHKAT, M.V. Influence of different osmopriming treatments on emergency and yield of maize (Zea mays L.). Research Journal of Biological Sciences, v.3, n.12, p.1452-1455, 2008. http://medwelljournals.com/ abstract/?doi=rjbsci.2008.1452.1455

HEYDECKER, W.; COOLBEAR, P.; TURNER, Y. J. Invigoration of seeds? Seed Science and Technology, v.3, n.4, p.881-888, 1975.

KHALIL, S. K.; MEXAL, J. G.; MURRAY, L. W. Germination of soybean seed primed in aerated solution of polyethylene glycol (8000). Online Journal of Biological Sciences, v.1, p.105-107, 2001. http://scialert.net/ abstract/?doi=jbs.2001.105.107

MARCOS-FILHO, J. Fisiologia de sementes de plantas cultivadas. Piracicaba: FEALQ, 2015. 659p.

MASETTO, T. E.; FARIA, J. M. R.; FRAIZ, A. C. R.; REZENDE, R. K. S. Condicionamento osmótico de sementes de Sesbania virgata (CAV) PERS (FABACEAE). Cerne, v.19, n.4, p.629-636, 2013. http://www.scielo.br/ scielo.php?script=sci_arttext\&pid=S0104-77602013000400013

MENEZES, N. L.; ESPINDOLA, M. C. G.; PASQUALI, L. L.; SANTOS, C. M. R.; FRANZIN, S. M. Associação de tratamentos pré-germinativos em sementes de alface. Revista da Faculdade de Zootecnia, Veterinária e Agronomia, v.13, n.1, p.1-11, 2006. http://revistaseletronicas.pucrs.br/ojs/ index.php/fzva/article/view/2334/1821

NAKAGAWA, J. Testes de vigor baseados no desempenho das plântulas. In: KRZYZANOSWKI, F.C.; VIEIRA, R.D.; FRANÇA-NETO, J.B. (Eds.). Vigor de sementes: conceitos e testes. Londrina: ABRATES, 1999, p.2.1-2.24.

OLIVEIRA, A.B.; GOMES-FILHO, E. Efeito do condicionamento osmótico na germinação e vigor de sementes de sorgo com diferentes qualidades fisiológicas. Revista Brasileira de Sementes, v.32, n.3, p. 25-34, 2010. http:// www.scielo.br/pdf/rbs/v32n3/v32n3a03.pdf 
OLIVEIRA, A. S.; SILVA-MANN, R.; SANTOS, M. F.; GOIS, I. B.; BARRETTO, M. C. V. Condicionamento osmótico em sementes de milho doce submetidas ao armazenamento. Revista Ciência Agronômica, v.38, n.4, p.444-448, 2007. http://ccarevista.ufc.br/seer/index.php/ccarevista/ article/view/108

PEREIRA, M. D.; DIAS, D. C. F. S.; DIAS, L. A. S.; ARAÚJO, E. F. Germinação e vigor de sementes de cenoura osmocondicionadas em papel umedecido e solução aerada. Revista Brasileira de Sementes, v.30, n.2, p.137-145, 2008. http://www.scielo.br/pdf/rbs/v30n2/a17v30n2.pdf

RAMEZANI, M.; SOKHT-ABANDANI, R. R. Effects of various different priming techniques on germination traits and seedling of corn (Zea mays S.C. 704). International Journal of AgriScience, v.3, n.2, p.149-156, 2013. http:// journaldatabase.info/articles/effects_various_different_priming.html

ROSA, S. D. V. S.; PINHO, E. V. R. V.; VIEIRA, M. G. G. C.; VEIGA, R. D. Eficácia do teste de condutividade elétrica para uso em estudos de danos de secagem em sementes de milho. Revista Brasileira de Sementes, v.22, n.1, p.5463, 2000. http://www.abrates.org.br/revista/artigos/2000/v22n1/artigo09.pdf
SEDIYAMA, C. A. Z.; REIS, M. S.; SEDIYAMA, C. S.; DIAS, M. A.; SEDIYAMA, T.; DIAS, D. C. F. S. Physiological quality of soybean seed cultivars by osmoconditioning. Comunicata Scientiae, v.3, n.2, p.90-97, 2012. http://www.comunicatascientiae.com.br/comunicata/article/view/88/117

SOKHT-ABANDANI, R. R.; RAMEZANI, M. The physiological effects on some traits of osmopriming germination of maize (Zea mays L.), rice (Oryza sativa L.) and cucumber (Cucumis sativus L.). International Journal of Biology, v.4, n.2, p.132-147, 2012. http://www.ccsenet.org/journal/index. php/ijb/article/view/16083/10841

YASARI, E.; SORAKI, S.Y.; SARAVI, K.O. Appraisal of the effects of osmopriming and hydro-priming treatments on the seeds of corn (Zea mays L.) cultivars. International Journal of Agronomy and Plant Production, v.4, p.195203, 2013. http://www.cabi.org/cabdirect/FullTextPDF/2013/20133097525.pdf

YOON, B. Y. H.; LANG, H. J.; COBB, B. G. Priming with salt solutions improves germination of pansy seed at high temperatures. HortScience, n.32, p.248-250, 1997. http://hortsci.ashspublications.org/content/32/2/248.full. pdf + html 